\title{
PENGARUH MODEL PEMBELAJARAN SNOWBALL THROWING TERHADAP HASIL BELAJAR SISWA PADA PEMBELAJARAN ILMU PENGETAHUAN ALAM (IPA) MATERI PERUBAHAN SIFAT BENDA DI KELAS V SD NEGERI PRAPAG KIDUL 01 KECAMATAN LOSARI KABUPATEN BREBES
}

Christin Indrayani, Dicky Surachman

Universitas Nahdlatul Ulama Cirebon

Email: Indrayanichristin@gmail.com, surachmandicky@gmail.com

Citasi: Indriyani, C., \& Surachman., D. (2019). Pengaruh Model Pembelajaran Snowball Throwing Terhadap Hasil Belajar Siswa Pada Pembelajaran Ilmu Pengetahuan Alam (IPA) Materi Perubahan Sifat Benda Di Kelas V Sd Negeri Prapag Kidul 01 Kecamatan Losari Kabupaten Brebes. Mangifera Edu volume 3 (2), 88-99.

\begin{abstract}
ABSTRAK
Masalah yang terdapat dalam penelitian ini adalah kurangnya respon siswa terhadap pembelajaran IPA, sehingga hasil belajar pada mata pelajaran IPA masih ada yang belum memenuhi Kriteria Ketuntasan Minimal (KKM) sebesar 70. Berdasarkan masalah tersebut, maka peneliti melakukan upaya agar pembelajaran pada mata pelajaran IPA menerapkan model pembelajaran snowball throwing. Penelitian ini bertujuan untuk mengetahui pengaruh dan respon siswa pada model pembelajaran snowball throwing terhadap hasil belajar siswa pada pembelajaran IPA materi perubahan sifat benda di kelas V SD Negeri Prapag Kidul 01 Kecamatan Losari Kabupaten Brebes. Penelitian ini merupakan penelitian eksperimen, yang menggunakan pendekatan kuantitatif. Populasi penelitian ini adalah siswa kelas $V$ sebanyak 24 siswa, sedangkan sampel pada penelitian ini menggunakan teknik pengambilan sampling yaitu dengan menggunakan sampel jenuh, dengan dibagi menjadi dua kelompok yaitu eksperimen dan kontrol dengan jumlah 12 siswa. Hasil penelitian menunjukkan pembelajaran dengan menerapkan model pembelajaran snowball throwing dapat meningkatkan hasil belajar mata pelajaran IPA. Peningkatan tersebut dapat dilihat dari hasil angket respon siswa dan uji hipotesis, berdasarkan hasil angket respon positif siswa terhadap model pembelajaran snowball throwing dari 12 siswa memperoleh sebesar 81,6\% atau dengan kriteria sangat kuat. Sedangkan hasil perhitungan uji hipotesis pada uji $\mathrm{N}$-Gain diperoleh kelompok eksperimen sebesar 84,93 sedangkan kelompok kontrol sebesar 52,37 dari hasil tersebut 84,93>52,37selain itu berdasarkan uji $T$ independent samples test memperoleh nilai $(\alpha)$ 0,025 > P value 0,000, maka $\mathrm{H}_{1}$ diterima dan $\mathrm{H}_{0}$ ditolak atau artinya model pembelajaran snowball throwing berpengaruh terhadap hasil belajar mata pelajaran IPA materi perubahan sifat benda pada siswa kelas V SD Negeri Prapag Kidul 01 Kecamatan Losari Kabupaten Brebes.
\end{abstract}

Kata kunci: Model pembelajaran snowball throwing, hasil belajar, pembelajaran IPA 


\section{PENDAHULUAN}

Pada dasarnya pendidikan memegang peranan penting dalam kehidupan karena pendidikan merupakan tempat untuk meningkatkan dan mengembangkan sumber daya manusia serta cita-cita bangsa. Untuk itu perlu dilakukan pembaharuan dalam bidang pendidikan dari waktu ke waktu. Serta upaya untuk mewujudkan kesejahteraan umum dan mencerdaskan kehidupan bangsa. Hal ini sebagaimana tercantum dalam Undang-Undang Republik Indonesia No. 20 tahun 2003 pasal 3, yaitu:

"Pendidikan nasional berfungsi mengembangkan kemampuan dan membentuk watak serta peradaban bangsa, bertujuan untuk berkembangnya potensi peserta didik agar menjadi manusia yang beriman dan bertakwa kepada Tuhan Yang Maha Esa, berakhlak mulia, sehat, berilmu, cakap, kreatif, mandiri dan menjadi warga negara yang demokratis serta bertanggung jawab".

Tujuan pembelajaran IPA di sekolah dasar menurut Departemen Pendidikan Nasional, (2003:27)“tujuannnya agar siswa mampu menguasai konsep IPA dan keterkaitannya serta mampu mengembangkan sikap ilmiah untuk memecahkan masalahmasalah yang dihadapinya sehingga lebih menyadari kebesaran dan kekuasaan PenciptaNya".

Dalam hal ini berdasarkan pengamatan yang dilakukan di SD Negeri Prapag Kidul 01 Kecamatan Losari Kabupaten Brebes terdapat masalah yang timbul dalam proses pembelajaran IPA kurang antusias dalam menerima pembelajaran karena guru menyajikan materi hanya melalui ceramah, tanya jawab dan penguasaan. Serta siswa kurang aktif dalam proses pembelajaran IPA, baik dalam hal mengajukan pertanyaan ataupun menjawab pertanyaan. Sehingga mengakibatkan kurangnya respon siswa terhadap pembelajaran IPA

Pembelajaran IPA siswa kelas V SD Negeri Prapag Kidul 01masih banyak guru yang menggunakan metode klasikal seperti ceramah dan diskusi serta guru mencatat di papan tulis dan siswa menyalin apa yang ditulis oleh guru. Sehingga siswa merasa bosan, meskipun guru sudah melaksanakan kegiatan pembelajaran secara baik, tetapi kenyataannya masih menunjukkan rendahnya hasil belajar yang dicapai oleh siswa.

Untuk mengatasi masalah di atas, maka penulis perlu menerapkan model-model pembelajaran yang menarik dan menyenangkan yang dapat membuat siswa aktif dalam proses pembelajaran, siswa dapat berinteraksi langsung dengan guru dan sesama temannya, dapat bertanya kepada guru tentang materi yang tidak dipahami, siswa dapat memiliki 
wawasan yang luas tentang pelajaran perubahan sifat benda, dan dapat menyelesaikan soalsoal latihan dengan benar. Salah satu model pembelajaran yang dapat digunakan untuk meningkatkan hasil belajar siswa adalah model pembelajaran snowball throwing.

Model pembelajaran snowball throwing ini adalah model pembelajaran yang dimodifikasi dari teknik bertanya yang dikemas dalam bentuk permainan yang menyenangkan, serta siswa bisa terlatih dalam menghadapi soal-soal IPA yang bervariasi dan berkaitan dengan keaktifan siswa dalam belajar. Model ini memiliki keunggulan untuk mendorong siswa untuk berfikir dan bergerak aktif selama pembelajaran serta melatih kesiapan siswa dalam mencapai tujuan pembelajaran. Dengan adanya model belajar yang berbeda akan berpengaruh pada ketertarikan siswa dalam pembelajaran. Motivasi dan hasil belajar memiliki kaitan yang erat karena hasil belajar dipengaruhi oleh pengalaman belajar seseorang. Menurut Fathurrohman (2015:61),model pembelajaran snowball throwing 'bola salju bergulir' merupakan model pembelajaran dengan menggunakan bola pertanyaan dari kertas yang digulung bulat berbentuk bola kemudian dilemparkan secara bergiliran diantara sesama anggota kelompok. Pada prinsipnya, model ini memadukan pendekatan komulatif, integratif dan keterampilan proses.Dari pendapat tersebut bahwa model pembelajaran snowball throwing merupakan model pembelajaran yang menggunakan bola pertanyaan dari kertas yang digulung bulat berbentuk bola kemudian dilempakan secara bergiliran kepada sesama anggota kelompok.

Menurut Suprijono (2011:8) snowball throwing adalah suatu cara penyajian bahan pelajaran dimana murid dibentuk dalam beberapa kelompok yang heterogen kemudian masing-masing kelompok dipilih ketua kelompoknya untuk mendapat tugas dari guru lalu masing-masing siswa membuat pertanyaan yang dibentuk seperti bola (kertas pertanyaan) kemudian dilempar ke siswa lain yang masing-masing murid menjawab pertanyaan dari bola yang diperoleh.

Berdasarkan latar belakang masalah yang telah dibahas, maka rumusan masalah pada penelitian ini adalah sebagai berikut.

1. Bagaimana pengaruh model pembelajaran snowball throwing terhadap hasil belajar siswa pada pembelajaran Ilmu Pengetahuan Alam (IPA) materi perubahan sifat benda di kelas V SD Negeri Prapag Kidul 01 Kecamataan Losari Kabupaten Brebes?

2. Bagaimana respon siswa terhadap model pembelajaran snowball throwing pada materiperubahan sifat benda terhadap hasil belajar siswa di kelas V SD Negeri Prapag Kidul 01 Kecamataan Losari Kabupaten Brebes?

3. 


\section{METODE PENELITIAN}

Menurut Sugiyono (2013:3) metodologi penelitian adalah cara ilmiah untuk mendapatkan data dengan tujuan dan kegunaan tertentu. Metodologi juga merupakan analisis teoritis mengenai suatu cara atau metode penelitian merupakan suatu penyelidikan yang sistematis untuk meningkatkan sejumlah pengetahuan, juga merupakan suatu usaha yang sistematis dan terorganisasi untuk menyelidiki masalah tertentu yang memerlukan jawaban.

Subyek penelitian ini adalah siswa kelas V SD Negeri Prapag Kidul 01 Kecamatan Losari Kabupaten Brebes yang berjumlah 24 siswa.

Pengambilan sampel dalam penelitian ini menggunakan sampel jenuh, menurut Sugiyono, (2015: 124) "sampling jenuh adalah teknik penentuan sampel bila semua anggota populasi digunakan sebagai sampel. Istilah lain dari sampel jenuh sensus, dimana semua anggota populasi dijadikan sampel”. Berdasarkan teknik tersebut, penelitian dilakukan di kelas V SD Negeri Prapag Kidul 01 Kecamatan Losari Kabupaten Brebes. Dalam penelitian ini, peneliti membagi dua kelompok belajar yaitu kelompok eksperimen dan kelompok kontrol dengan jumlah yang sama. Pembagian siswa dipilih secara acak. Kelas eksperimen adalah kelompok siswa yang mendapat perlakuan dengan menggunakan model snowball throwing yakni sebanyak 12 siswa, sedangkan kelas kontrol adalah kelompok siswa yang mendapat perlakuan dengan menggunakan motode pembelajaran ceramah yakni sebanyak 12 siswa.

Adapun instrumen yang digunakan dalam penelitian ini terdiri atas dokumen dan instrumen pengumpulan data, di antaranya yaitu:

\section{Dokumen}

Sugiyono (2012:240) berpendapat bahwa dokumen merupakan catatan peristiwa yang sudah bc erlalu. Dokumen bisa berbentuk tulisan, gambar, atau karya-karya monumental dari seseorang. Dari pendapat tersebut dokumen adalah catatan yang sudah berlalu yang bisa berbentuk tulisan, serta gambar. Dokumen yang digunakan dalam penelitian ini berupa Rencana pelaksaan pembelajaran (RPP), serta buku paket dan soal tes.

\section{Tes}

Menurut Suharsimi (2013:193), tes adalah serentetan pertanyaan atau latihan serta alat lain yang digunakan untuk mengukur keterampilan, pengetahuan, inteligensi, kemampuan atau bakat yang dimiliki oleh individu atau kelompok.

Dari pendapat di atas bahwa tes ada instrumen tes yang digunakan dalam penelitian ini adalah berupa soal uraian yang disususn berdasarkan indikator-indikator dari kemampuan 
keterampilan siswa, soal tes yang dibuat juga memperhatikan aspek-aspek dari kemampuan pemahaman siswa mengenai materi tersebut. Adapun indikator-indikator kemampuan keterampilan siswa adalah sebagai berikut:

1) Siswa mampu membuat dan menjawab pertanyaan.

2) Siswa mampu menggali potensi kepemimpinan.

3) Siswa mampu melakukan percobaan perubahan sifat benda dengan benar dan baik.

Soal divalidasi terdiri dari soal pre-test dan post-test.

\section{Angket atau Kuesioner}

Menurut Riduwan (2014:52) angket atau kuesioner adalah daftar pertanyaan yang diberikan kepada orang lain bersedia memberikan repon (responden) sesuai dengan permintaan pengguna.

Dengan menggunakan angket maka dapat kita ketahui keberhasilan pembelajaran dengan menggunakan model pembelajaran snowball throwing. Instrumen angket dalam penelitian ini bertujuan untuk mengetahui respon siswa terhadap penggunaan model snowball throwing yang dilaksanakan di kelas eksperimen. Angket sebagai alat penilaian digunakan untuk mengetahui pendapat, aspirasi, harapan, keinginan dan lain-lain sebagai hasil belajar siswa. Cara yang dilakukan dalam instrumen angket dalam penelitian ini dengan cara mengajukan pertanyaan kepada siswa secara tertulis dalam bentuk pertanyaan objektif mengenai pembelajaran IPA dengan penggunaan model snowball throwing.

Dalam teknik analisis data, penelitian ini melalui beberapa langkah yaitu sebagai berikut:

1. Uji Instrumen

Dalam uji instrumen, penulis menggunakan perhitungan uji validitas dan uji reliabilitas.

1) Validitas Tes

Untuk menghitung koefisien validitasnya, peneliti menggunakan rumus korelasi product moment sebagai berikut:

$$
r_{x y}=\frac{N \sum X Y-\left(\sum X\right)\left(\sum Y\right)}{\sqrt{\left[N \sum X^{2}-\left(\sum X\right)^{2}\right]\left[N \sum Y^{2}-\left(\sum Y\right)^{2}\right]}}
$$

\footnotetext{
Keterangan:

$r_{x y}=$ koefisien korelasi dari variabel $\mathrm{X}$ dan $\mathrm{Y}$

$\mathrm{N}$ = banyaknya siswa yang mengikuti tes
} 


$$
\begin{aligned}
& \mathrm{X}=\text { nilai uji coba tes } \\
& \mathrm{Y}=\text { nilai rata-rata tes } \\
& \text { 2) } \quad \text { Uji Reabilitas }
\end{aligned}
$$

Uji reabilitas dimaksudkan untuk mengetahui adanya konsistensi (ajeg) alat ukur dalam penggunaannya, dengan kata lain, alat ukur tersebut mempunyai hasil yang konsisten apabila digunakan berkali-kali pada waktu yang berbeda.Cara menentukan reabilitas:

a) Menentukan nilai varians setiap butir soal

$$
\mathrm{S}_{1}^{2}=\frac{\sum x_{1}^{2}-\frac{\left(\sum x_{1}\right)^{2}}{n}}{\mathrm{n}}
$$

Keterangan :

$$
\begin{aligned}
& \mathrm{n} \quad=\text { banyaknya butir soal } \\
& S_{1}^{2}=\text { varians skor total } \\
& \mathrm{n} \quad=\text { banyaknya sampel atau peserta tes } \\
& \mathrm{xi} \quad=\text { skor butir soal ke-i } \\
& \mathrm{i} \quad=\text { nomor soal }
\end{aligned}
$$

\section{Uji Prasyarat}

1) Uji Normalitas

Pada penelitian ini, penulis menggunakan chi kuadrat untuk menguji normalitas data dengan rumus sebagai berikut dengan bantuan IBM SPSS versi 23:

$$
X^{2}=\sum_{i=1}^{k} \frac{\left(f i-f_{o}\right)^{2}}{f_{O}}
$$

Keterangan:

$$
\begin{array}{ll}
\mathrm{X}_{2} & =\text { chi kuadrat } \\
\mathrm{F}_{\mathrm{i}} & =\text { frekuensi yang diobservasi } \\
\mathrm{f}_{0} & =\text { frekuensi yang diharapkan }
\end{array}
$$

Hasil yang diperoleh probabilitas (sig.) dibandingkan dengan taraf signifikan 5\% atau 0,05. Jika nilai sig. $>0,05$ maka data normal dan jika nilai sig. $<0,05$ maka data tidak normal.

2) Uji Homogenitas

Rumus uji statistis yang digunakan adalah $F=\frac{S_{1}^{2}}{S_{2}^{2}}$

Keterangan: 
$\mathrm{F}=$ homogenitas yang dicari

$S_{1}^{2}=$ varians besar

$S_{2}^{2}=$ varians kecil

Hasil yang diperoleh dari $F_{\text {hitung }}$ selanjutnya dibandingkan dengan $F_{\text {tabel }}$ dengan menentukan derajat kebebasan $\left(\mathrm{dk}_{1}\right)=\left(\mathrm{n}_{2}-1\right)$ dan $\left(\mathrm{dk}_{2}\right)=\left(\mathrm{n}_{2}-1\right)$ dengan taraf signifikan $\alpha=5 \%$.

Dikatakan kelompok eksperimen dan kelompok kontrol berasal dari populasi yang dimiliki varians yang relative sama apabila $F_{\text {hitung }}<F_{\text {tabel }}$ maka data tersebut berdistribusi homogen.

\section{Uji Hipotesis}

a. Uji N-Gain

Menurut Hake untuk menghitung $n$-gain menggunakan rumus sebagai berikut:

$$
g=\frac{S_{\text {post }}-S_{\text {pre }}}{S_{\text {mak }}-S_{\text {pre }}}
$$

Keterangan:

g = N-gain

$S_{\text {post }}=$ Skor Post test

$S_{\text {pre }}=$ Skor Test

$S_{m a k}=$ Skor Maksimal Soal

b. Uji T

Uji t digunakan untuk mengetahui ada atau tidak adanya perbedaan antara dua buah data. Rumus yang digunakan adalah:

$$
t_{\text {hitung }}=\frac{\bar{x}_{1}-\bar{x}_{2}}{\sqrt{\frac{(n-1) S_{1}^{2}+(n-1) S_{2}^{2}}{n_{1}+n_{2}-2}\left(\frac{1}{n_{1}}+\frac{1}{n_{2}}\right)}}
$$

Hipotesis:

$\mathrm{H}_{0} \quad$ : jika tidak ada perbedaan nila rata-rata antara kelas eksperimen dan kelas kontrol.

$\mathrm{H}_{1} \quad$ : jika ada perbedaan nilai rata-rata antara kelas eksperimen dan kelas kontrol.

Jika, 
$t_{\text {tabel }} \geq t_{\text {hitung }}$ maka $\mathrm{H}_{0}$ diterima

$t_{\text {tabel }}<t_{\text {hitung }}$ maka $\mathrm{H}_{0}$ ditolak dan $\mathrm{H}_{1}$ diterima

\section{HASIL DAN PEMBAHASAN}

Untuk mengetahui besarnya pengaruh model snowball throwing dengan melakukan perhitungan sebagai berikut:

1. Besarnya kenaikan setelah menggunakan model snowball throwing

$$
\begin{array}{ll}
\text { Kelas Eksperimen (Model Snowball Throwing) } & =85.93 \% \\
\text { Kelas Kontrol (Metode Ceramah) } & =48,98 \% \\
\text { Perbedaan } & =\overline{36,95 \%}
\end{array}
$$

Hasil uji N-gain dapat juga dilihat dari diagram rata-rata peningkatan hasil belajar pada kelompok eksperimen dan kontrol. Yang dapat dilihat pada gambar 4.5 yaitu sebagai berikut:

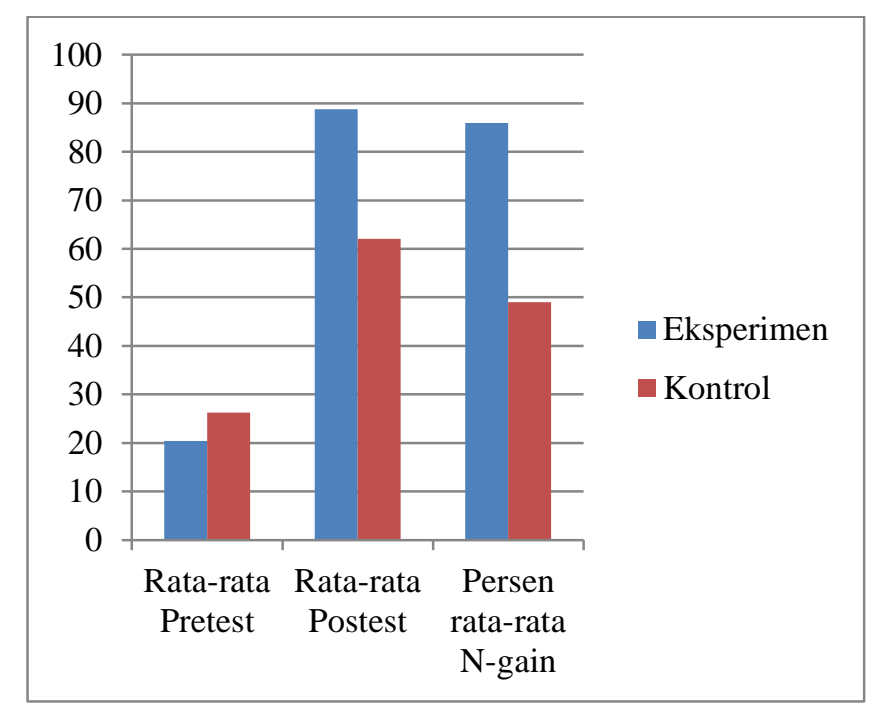

Gambar 1. Diagram Perbandingan peningkatan hasil belajar siswa.

Berdasarkan dari hasil angket dapat dikategorikan yang menjawab positif dan negatif. Adapun datanya dalam tabel, yaitu sebagai berikut:

Tabel 1 Rekapitulasi Hasil Perhitungan Angket

\begin{tabular}{cccc}
\hline No Item & \multicolumn{2}{c}{ Pernyataan } & \multirow{2}{*}{ Jumlah } \\
\cline { 2 - 3 } Pernyataan & Positif & Negatif & \\
\hline 1 & 12 & 0 & 12 \\
\hline
\end{tabular}




\begin{tabular}{cccc}
\hline 2 & 12 & 0 & 12 \\
3 & 8 & 4 & 12 \\
4 & 7 & 5 & 12 \\
5 & 12 & 0 & 12 \\
6 & 8 & 4 & 12 \\
7 & 12 & 0 & 12 \\
8 & 12 & 0 & 12 \\
9 & 8 & 4 & 12 \\
10 & 9 & 3 & 12 \\
11 & 10 & 2 & 12 \\
12 & 9 & 3 & 12 \\
13 & 9 & 3 & 12 \\
14 & 8 & 4 & 12 \\
15 & 12 & 12 & 12 \\
Jumlah & 148 & 32 & 180 \\
Rata-rata & 9,86667 & 2,93333 & 12 \\
Persentasi & 81.6 & 24.2 & 100 \\
Interpretasi & Respon Sangat Kuat \\
\hline
\end{tabular}

Berdasarkan hasil tabel 1 rekapitulasi hasil perhitungan angket, Jumlah pernyataan positif dan negatif respon siswa jumlah pernyataan positif 81,6\% sedangkan pada jumlah pernyataan negatif $24,2 \%$, sehingga dapat diambil kesimpulan bahwa interprestasi respon siswa sangat kuat terhadap mata pelajaran IPA perubahan sifat benda dengan menggunakan model pembelajaran snowball throwing.

Penelitian ini dilakukan di SD Negeri Prapag Kidul 01 Kecamatan Losari Kabupaten Brebes, populasi dalam penelitian ini yaitu kelas V yang berjumlah 24 siswa. Penulis menetapkan untuk sampel dalam penelitian ini menggunakan sampel jenuh. Kemudian dibagi dua kelompok, yaitu kelompok eksperimen dan kelompok kontrol, kelompok eksperimen merupakan kelompok belajar yang mendapat perlakuan menggunakan model pembelajaran snowball throwing, sedangkan kelompok kontrol merupakan kelompok yang menggunakan pembelajaran dengan menggunakan motode ceramah. Masing-masing kelompok berjumlah sebanyak 12 siswa, sedangkan pembagian kelompok dipilih berdasarkan tempat duduk agar memudahkan peneliti untuk membagi siswa. Variabel bebas dalam penelitian ini adalah model pembelajaran snowball throwing, sedangkan variabel terikatnya adalah hasil belajar mata pelajaran IPA materiperubahan sifat benda. Penelitan ini bertujuan untuk menganalisis pengaruh model pembelajaran snowball throwing terhadap hasil belajar pada pembelajaran IPA materi perubahan sifat bendadi kelas V SD Negeri Prapag Kidul 01 Kecamatan Losari Kabupaten Brebes. 
Sebelum penelitian ini dilakukan peneliti melakukan uji instrumen terlebih dahulu oleh dosen mata pelajaran Ilmu pengetahuan Alam (IPA) serta guru kelas V serta di uji instrumen di kelas VI SD Negeri Prapag Kidul 01 untuk mempersiapkan soal instrumen yang valid dan ajeg, dengan jumlah soal sebanyak 25 soal instrumen dan sebanyak 24 siswa yang mengikuti uji instrumen. Hasil yang diperoleh dalam uji instrumen sebanyak 25 soal ada 20 soal yang dapat dipakai untuk penelitian yaitu soal bernomor3, 4, 5, 6, 7, 8, 10, 11, 12, 13, $14,15,17,18,19,21,22,23,24$, dan 25 .

Setelah itu, peneliti melakukan penelitian pada dua kelompok yaitu kelompok eksperimen dan kontrol. Kelompok eksperimen mendapatkan dua evaluasi belajar yaitu pembelajaran berkelompok dan individu, sedangkan pada kelompok kontrol hanya ada evaluasi individu. Hasil evaluasi pada kelompok eksperimen dari empat kelompok mendapat nilai rata-rata sebesar 81,25 .

Sedangkan hasil evaluasi individu kedua kelompok setelah diberi pretest dan postest, hasil belajar IPA dari ke dua kelompok sampel. Kelompok eksperimen dengan jumlah siswa sebanyak 12 siswa diperoleh hasil nilai rata-rata pretest sebesar 20,42 dan hasil nilai ratarata postest sebesar 88,75 . Sedangkan pada kelompok kontrol diperoleh hasil nilai pretest sebesar 26,25 dan hasil nilai rata-rata postest sebesar 62,08. Kemudian kedua data tersebut dibandingkan antara hasil nilai postest kelompok eksperimen dan postest kelompok kontrol, pada prosesnya pembelajaran dengan menggunakan model pembelajaran snowball throwing lebih unggul dibandingkan pembelajaran dengan metode ceramah. Shoimin (2016) mengemukakan bahwa dengan mengubah model pembelajaran ceramah, kepada model pembelajaran yang dinamis dan lebih bermakna seperti pembelajaran dengan menggunakan model snowball throwing, maka akan terbuka kesempatan siswa untuk membangkitkan cara berpikir kritis dan dengan hasil pembelajaran yang lebih baik serta dapat meningkatkan hasil belajar.

Dari hasil uji hipotesis statistik dengan menggunakan uji N-Gain memperoleh ratarata pretest dan postest kelompok eksperimen diperoleh nilai $\mathrm{N}$-gain sebesar 0,85 atau $85,93 \%$. Sedangkan n-gain pada pretest dan postest kelompok kontrol diperoleh nilai N-gain sebesar 0,48 atau 48,98\% Diinterprestasikan dengan tabel $\mathrm{N}$-gain, untuk kelompok eksperimen sebesar 85,93\%. tinggi dan untuk kelompok kontrol 48,98\% sedang. Selain itu, berdasarkan hasil uji hipotesis statistik dengan menggunakan uji $\mathrm{T}$ memperoleh nilai berdasarkan perbandingan probabilitas sebesar $(\alpha) 0,025>\mathrm{P}$ value 0,000 , maka dapat dinyatakan bahwa $H_{l}$ diterima dan $H_{0}$ ditolak sedangkan berdasarkan perbandingan $t_{h i t u n g}$ dan $\mathrm{t}_{\text {tabel }}$ yaitu $\mathrm{t}_{\text {hitung }}$ sebesar 7,966 sedangkan $\mathrm{t}_{\text {tabel }}=\mathrm{t}_{(24-2)}=22$ karena menggunakan 2 sisi ( $\operatorname{sig} 2-$ 
tailed) jadi sebesar 2,074 selanjutnya membandingkan antara thitung dan tabel diperoleh $t_{\text {hitung }}>t_{\text {tabel }}$ atau 7,966>2,819 artinya model pembelajaran snowball throwing berpengaruh terhadap hasil belajar mata pelajaran IPA materi perubahan sifat benda pada siswa kelas V SD Negeri Prapag Kidul 01 Kecamatan Losari Kabupaten Brebes. Hasil penelitian ini sejalan dengan hasil penemuan dari Fulfita Musliana (2013) yang menemukan adanya pengaruh positif terhadap hasil nilai posttest siswa dibandingkan nilai pretest dalam penggunaan model pembelajaran snowball throwing. Dengan demikian terdapat pengaruh pada model pembelajaran snowball throwing terhadap hasil belajar siswa pada mata pelajaran IPA materi perubahan sifat benda. Dengan terbuktinya hasil uji N-Gain dan uji hipotesis statistik dengan menggunakan uji T kelompok eksperimen lebih besar dibandingkan kelompok kontrol.

Sedangkan berdasarkan dari hasil data angket dapat disimpulan bahwa 81,6\% siswa memiliki respon positif dan $24,2 \%$ memiliki respon negatif terhadap pembelajaran model snowball throwing dapat di katagorikan respon yang sangat kuat. Hal ini menujukan bahwa minat siswa terhadap mata pelajaran IPA materi perubahan sifat benda dengan menggunakan model pembelajaran snowball throwing SANGAT KUAT. Munadi (2008), mengungkapkan bahwa faktor-faktor yang mempengaruhi hasil belajar meliputi faktor internal dan eksternal. Dalam pembelajaran diperlukannya faktor internal di antaranya faktor fisiologis dan psikologis dengan adanya faktor fisiologis seperti kondisi kesehatan siswa, tidak boleh dengan keadaan yang sakit karena dapat mempengaruhi hasil belajar siswa, serta faktor psikologis meliputi minat dan motivasi siswa terhadap pembelajaran IPA dengan menggunakan model pembelajaran snowball throwing. Dengan demikian terbukti dari hasil angket dimana siswa memiliki respon positif sebesar $81,6 \%$ dan siswa memiliki respon negatif sebasar $24,2 \%$.

\section{KESIMPULAN}

Berdasarkan rumusan masalah dan hipotesis penelitian yang diajukan, serta hasil penelitian yang didasarkan pada pengolahan data dan pengujian hipotesis, dengan demikian kesimpulan yang dapat dikemukakan dalam penelitian ini adalah:

Hasil belajar mata pelajaran IPA materi perubahan sifat benda pada siswa kelas V SD Negeri Prapag Kidul 01 Kecamatan Losari Kabupaten Cirebon dalam penelitian ini dapat disimpulkan model pembelajaran snowball throwing berpengaruh terhadap hasil belajar mata pelajaran IPA materi perubahan sifat benda pada siswa kelas V SD Negeri Prapag Kidul 01 Kecamatan Losari Kabupaten Brebes. 
Berdasarkan dari hasil data angket dapat disimpulan bahwa 81,6\% siswa memiliki respon positif dan $24,2 \%$ memiliki respon negatif terhadap pembelajaran model snowball throwing dapat di katagorikan respon yang sangat kuat. Hal ini menujukan bahwa minat siswa terhadap mata pelajaran IPA materi perubahan sifat benda dengan menggunakan model pembelajaran snowball throwing SANGAT KUAT

\section{DAFTAR PUSTAKA}

Arikunto, Suharsimi. 2013. Prosedur Penelitian. Jakarta: Rineka Cipta.

Fathurrohman, Muhammad. 2015. Model-Model Pembelajaran Inovatif. Yogyakarta: ArRuzz Media.

Komalasari, Kokom. 2010. Pembelajaran Kontekstual. Bandung: PT. Refika Aditama.

Kurniasih, Imas. dan Berlin Sani. 2016. Ragam Pengembangan Model Pembelajaran. Jakarta: Kata Pena.

Huda, Miftahul.2013. Model-Model Pengajaran dan Pembelajaran. Yogyakarta: Pustaka Pelajar

Riduwan. 2010. Metode dan Teknik Menyusun Proposal Penelitian. Bandung: C.V. Alfabeta.

Rusman. (2010). Model-Model Pembelajaran. Bandung: PT. Rajagrafindo Persada.

Rusman. 2015. Pembelajaran Tematik Terpadu. Jakarta: PT. Rajagrafindo Persada.

Shoimin, Aris. 2016. 68 Model Pembelajaran Inovatif dalam Kurikulum 2013. Yogyakarta: Ar-Ruzz Media.

Sholeh, Abdul. 2015. Konsep Dasar IPA untuk PGSD/PGMI. Bandung. Mujahid Press.

Suprijono, Agus. 2012. Cooperatif Learning. Yogyakarta: Pustaka Pelajar. 